\title{
エタノール長期摂取のラット耳下腺に及はす影響に 関する実験的研究
}

\author{
松尾雅敦
}

\section{Experimental study on the effect of long-term ethanol intake on the rat parotid glands}

\author{
Masaatsu MAtsuo
}

\begin{abstract}
To elucidate the effect of long-term intake of ethanol on the parotid gland, observations of parotid glands from male Wistar Strain rats given $20 \%$ ethanol ad lib. instead of water were performed, using light and electron microscopy.

Results were as follows: (1) Under the light microscope, 3 rats (11\%) demonstrated several lesions involving complete lobular units, and (2) under the electron microscope, the earliest and most consistent changes after ethanol intake were the irregular formation of microvilli and interdigitation between parenchymal cells. These were accompanied by widening of the intercellular spaces and disappearance of the basal infolding structure with severe mitochondrial alteration in striated duct cells. Tortous proliferation of intercalated duct cells was observed after 4 months of ethanol intake.

These results suggest that the intake of ethanol leads to injury of the inter-parenchymal cell membranes and to the basal membranes of striated duct cells. Repeated degeneration and regeneration of duct cells during the repair process results in deformation of ductal structure at the level of the intercalated ducts, followed by the degeneration and subsequent atrophy of the acini.
\end{abstract}

Key words: ethanol (エタノール), parotid gland (耳下腺), rat (ラット)

緒 言

アルュールによる耳下腺の変化としては, アルュール 常習者に打ける無症候性腫大がよく知られている的． Borsanyi ら"1) はフルコール性肝硬変患者の $30 \%$ に, Abelson ら 2) は60〜80\%に両側性の耳下腺の腫大を認め ている。耳下腺腫大の原因は腺房細胞の肥大や間質にお ける脂肪蓄積などで，導管には変化がみられないとする 報告や ${ }^{3,4)}$ ，造影によって枯れ木状の所見を得たとする

東北大学䓶学部口腔外科学第 2 諈座

（主任：手島貞一教授）

Second Department of Oral Surgery, Tohoku University School of Dentistry (Chief: Prof. Teiichi Teshima)

受付日：昭和63年10月11日
報告などがあるら．

耳下腺の無症候性腫大は, アルコール常習のほかに栄 養障害 ${ }^{8 \sim 10)}$ ，糖尿病 ${ }^{11 \sim 13)}$ などによっても起こることが多 数報告されている。このような局所的疾患によらない無 症候性，両側性に腫大をきたす唾液腺の状態をSeifert ${ }^{14}$ ) は Sialadenose (唾液腺症) と総称し, その発症は耳下 腺に多く，腫大の原因は腺房細胞の肥大，增殖および間 質に怙ける脂肪蓄積であると述べている。

アルコールが各蔵器に及ぼす影響に関する㬰験は, 肝, 膵を中心に数多く行われている15 18). しかし, アル コールが耳下腺組織に与える影響に着目して行われた実

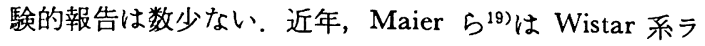
ットに 3 か月間エタノールを経口投与し光顕的㭘索を行 い, 腺房細胞における著明な脂肪蓄積があること, ヒト における報告に比べると耳下腺が萎縮する傾向にあるこ とを報告し，電顕的検索の必要性を述へている。そこ 
表 1 食触組成

\begin{tabular}{|c|c|}
\hline 成 分 & $\%$ \\
\hline 澱粉 & 48. 0 \\
\hline カ ピイン & 25.0 \\
\hline セルロース & 8.0 \\
\hline 装 粒 油 & 6.0 \\
\hline 価: 機 物 & 6.0 \\
\hline ブドウ 糖 & 5.0 \\
\hline ビタ ミン & 2. 0 \\
\hline 尌 & 100.0 \\
\hline リ $-/ 100 \mathrm{~g}$ & 332.8 \\
\hline
\end{tabular}

で，著者は，エタノール長期投与時における耳下腺の病 変を解明する目的で, Wistar 系ラットに $20 \%$ エタノー ルを経口投与し，耳下腺の光顕的ならびに電晋的検索を 行ったので報告する。

\section{実験材料および方法}

体重 $100 \mathrm{~g}$ 前後の同腹, 雄の Wistar 系ラット80匹を 用い，表 1 に示すよらな標準全にて 4 か月間飼育した。 その後, $20 \%$ エタールを投与したェタノール群と, 飲 料水を投与した対照群にわけて館育した。そして，表 2 に示すよらな時期にェーテル深麻酔下にて屠殺し, 耳下 㟫を摘出して光顕的ならびに電顕的検索を施行した。

上記方法で摘出した耳下腺の一部を, カコジル酸緩衝 液で PH 7.4 に調製した $5 \%$ グルタールアルデヒドおよ び $4 \%$ パラホルムアルデヒド混合液を用い, $4{ }^{\circ} \mathrm{C} に て ~ 3$ 時間前固定の後, カコジル酸緩衝液で一昼夜洗㴔した。 その後, カコジル酸緩衝液でPH 7.4 に調製した $1 \%$ 四 酸化オスミウムを用い，2 時閒の後固定を行った。

固定した材料はェタノールで脱水, 酸化プロピレンで 処理し, Luft ${ }^{20)}$ の方法にしたがって Epon 812 に包埋し た。これより超薄切片を作製し, 酢酸ウランとクェン酸 鉛による重染色を行い, JEM $100 \mathrm{CX}$ 型電子顕微鏡に て検索を行った。

さらに，摘出した耳下腺の他の一部を10\%ホルマリン 緩衝液にて固定し, Hematoxylin and Eosin stain $(\mathrm{H}$ \& E), Periodic Acid Shiff stain (PAS), Gomori's aldehyde fuchsin stain, PAS-alcian blue-Masson's trichrome stain などを行い，これを光顕的検索に使用し た.

\section{実 験 成 績}

\section{1. 体重の变動と死亡数}

飼育開始時の全ラットの体重平均値は $101 \mathrm{~g} て ゙ ， 4$ か
表 2 各呤育期間にお㞴るラット数

\begin{tabular}{|c|c|c|c|c|c|}
\hline \multicolumn{3}{|c|}{ 対 照 群 } & \multicolumn{3}{|c|}{ エタノ一ル群 } \\
\hline $\begin{array}{l}\text { 飼 } \\
\text { 育 } \\
\text { 期 } \\
\text { 間 } \\
\text { 月 } \\
\text { 数 }\end{array}$ & $\begin{array}{l}\text { ラ } \\
\% \\
\text { 卜 } \\
\text { 数 }\end{array}$ & $\begin{array}{c}\text { 死 } \\
\text { 亡 } \\
\text { ラ } \\
\text { \% } \\
\text { ト } \\
\text { 数 }\end{array}$ & $\begin{array}{l}\text { 投 } \\
\text { 与 } \\
\text { 期 } \\
\text { 間 } \\
\overbrace{\text { 数 }}\end{array}$ & $\begin{array}{c}\text { ラ } \\
, \\
\text { r } \\
\text { 数 }\end{array}$ & $\begin{array}{c}\text { 死 } \\
亡 \\
\text { 亡 } \\
\% \\
\text { 卜 } \\
\text { 数 }\end{array}$ \\
\hline 5 & 3 & 1 & 1 & 3 & 1 \\
\hline 6 & 3 & & 2 & 3 & 1 \\
\hline 7 & 3 & 2 & 3 & 3 & \\
\hline 8 & 3 & 3 & 4 & 3 & \\
\hline 10 & 5 & & 6 & 3 & \\
\hline 12 & 3 & & 8 & 3 & \\
\hline 14 & 3 & & 10 & 3 & \\
\hline 16 & 3 & 2 & 12 & 3 & 2 \\
\hline 22 & & 2 & 18 & & 2 \\
\hline 26 & & & 22 & 3 & 3 \\
\hline 28 & & & 24 & & 4 \\
\hline 計 & 26 & 10 & & 27 & 13 \\
\hline
\end{tabular}

飼育期間 4 か月内に 4 匹死亡

月後には $464 \mathrm{~g}$ となった。各実騟時における対照群とエ タノール群のラット体重の平均を図1に示した。対照群 ではしだいに体重が増加し，飼育期間16か月では平均值 は $665 \mathrm{~g}$ であった。これに対してェタノール群ではェタ ノール投与 1 か月から体重は減少し，エタノール投与 6 か月後から堌加の傾向を示し，エタノール投与12か月で 平均値は $557 \mathrm{~g}$ となった。

死亡数は表 2 に示すよ5に80匹中27匹であった。対照 群では36匹中 10 匹 $(28 \%)$, ェタノール群では40匹中13 匹 $(33 \%)$ で，泪群の死亡率の間には有意の差は認めら れなかった $(\mathrm{P}<0.05)$.

\section{2. 光顕的所見}

1) 腺房紏胞

腺房紐胞の光䫓的所兒の概要を表了に示した。

エタノール投与期間が長くなるにしたがって腺房部は 萎樎し, 腺房細胞数も減少する傾向を示し, エタノール 投与 4 か月から線維化と分泌顆粒の減少がみられた。

分泌顆粒には PAS-alcian blue-Masson's trichrome stain で赤沈する顆粒と青染する顆粒とがあり，一つの 腺房細胞に 2 種類の顆粒が混在することはなかった。対 照群においてはほとんどが赤染する顆粒で，青染する顆 粒は夹験後期に一部にみられた程度であった。しかし， エタノール群ではェタノール投与 3 か月から後者が含ま れるようになり，エタノール投与10か月以後のラットで その占める割合が多くなった。

腺房緗胞の配列の不整, 空胞形成, 脂肪变性は, 対照 


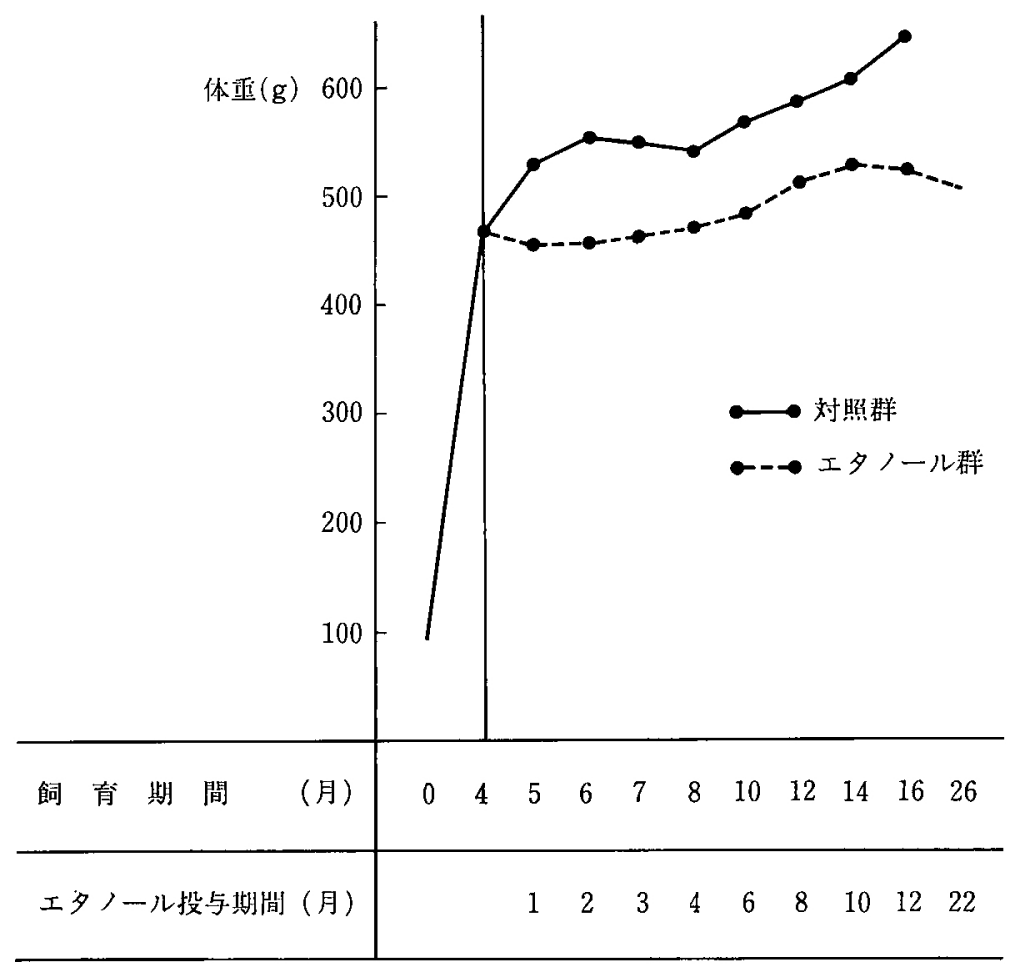

図 1 対照群とェタノール群の体重変動の比校

群においてる軽度ながら初期から観察され，エタノール 投与によってこれらが著明に增加する傾向はとくに認め られなかった。

エタノール投与10か月のラットは 3 匹とも線維化を伴 った小葉単位の高度の変性像を示し，この変性した小葉 では腺房細胞における分泌顆粒の減少, 腺房細胞の減 少, 萎縮, 腺腔の扗大, 配列の不整が著明に認められた (写真1).さらに，介在部導管は㹨窄あるい性張しな がら延長し，腺房部に比べて相対的な增加を示し，線維 化を伴う導管增生の像を呈していた。れと類似した変 性像は，エタノール投与 4 か月の 3 匹，投与 6 か月の 1 匹，投与 $12 か$ 月の 2 匹，投与 22 加の 2 匹の計 8 匹の ットに和いて小葉内に散在性汇認められた。

2) 介在部導管

介在部導管の光顕的所見の概要を表 4 K示した。

導管細胞の管腔側には PAS 染色で赤染する顆粒が多 数みられたが，エタノール投与による変化はほとんど認 められなかった。

対照群ではほとんどみられなかった導管の増生, 払張 が，エタノール群ではエタノール投与 4 か月からみられ る頻度が高くなった。 エタノール投与 4 か月以後のラッ ト18匹のらち15匹（83\%）に执张か，14匹（78\%）に増 生が認められた。

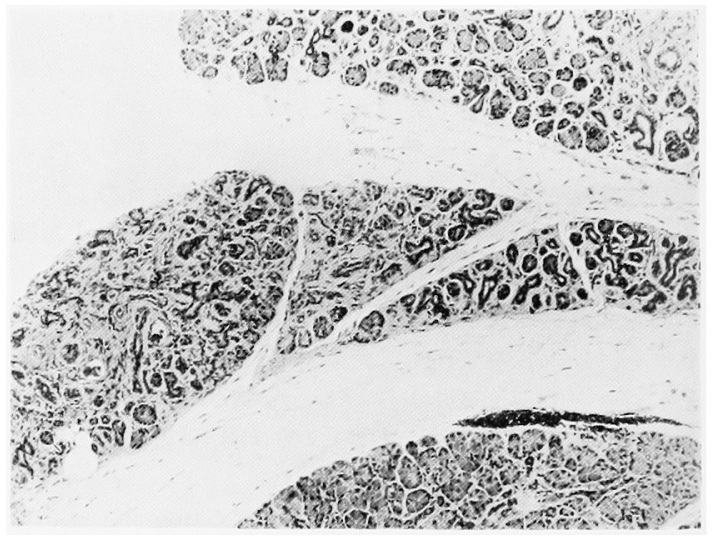

写真 1 耳下腺の光䫓伭

（ラットNo. 45 ×ノール投与 10 か月）介在部導 管の增生, 腺房細胞の著縮, 分泌顆粒の減少, 腺房 腔の桩張, 線維化が小葉単位で観察される、H-E 染色, $\times 50$

管腔内の眝溜物は両群においてはとんよ゙みられなかっ た。

3) 線条部導管

線条部導管の光顕的所見の概要を表 5 に示した。 
表 3 腺房部の光顕的所見

\begin{tabular}{|c|c|c|c|c|c|c|c|c|c|c|c|c|c|}
\hline \multicolumn{3}{|r|}{ 対 } & 照 & 群 & & & \multicolumn{7}{|c|}{ エタノール群 } \\
\hline $\begin{array}{c}\text { 飼 } \\
\text { 育 } \\
\text { 期 } \\
\text { 間 } \\
\text { a }\end{array}$ & $\begin{array}{c}\text { ラ } \\
\% \\
\text { ト } \\
\mathrm{NQ} .\end{array}$ & $\begin{array}{l}\text { 腺 } \\
\text { 腔 } \\
\text { の } \\
\text { 拡 } \\
\text { 張 }\end{array}$ & $\begin{array}{l}\text { 配 } \\
\text { 列 } \\
\text { の } \\
\text { 不 } \\
\text { 整 }\end{array}$ & $\begin{array}{c}\text { 空 } \\
\text { 胞 } \\
\text { 形 } \\
\text { 成 } \\
\text { b }\end{array}$ & $\begin{array}{c}\text { 脂 } \\
\text { 肪 } \\
\text { 変 } \\
\text { 性 } \\
\mathrm{c}\end{array}$ & $\begin{array}{l}\text { 線 } \\
\text { 維 } \\
\text { 化 }\end{array}$ & $\begin{array}{c}\text { 投 } \\
\text { 与 } \\
\text { 期 } \\
\text { 間 } \\
\mathrm{d}\end{array}$ & $\begin{array}{c}\text { ラ } \\
ッ \\
\text { ト } \\
\mathrm{NQ}\end{array}$ & $\begin{array}{l}\text { 腺 } \\
\text { 腔 } \\
\text { の } \\
\text { 拡 } \\
\text { 張 }\end{array}$ & $\begin{array}{l}\text { 配 } \\
\text { 列 } \\
\text { の } \\
\text { 不 } \\
\text { 整 }\end{array}$ & $\begin{array}{l}\text { 空 } \\
\text { 胞 } \\
\text { 形 } \\
\text { 成 }\end{array}$ & $\begin{array}{l}\text { 脂 } \\
\text { 肪 } \\
\text { 変 } \\
\text { 性 }\end{array}$ & $\begin{array}{l}\text { 線 } \\
\text { 維 } \\
\text { 化 }\end{array}$ \\
\hline 5 & $\begin{array}{l}1 \\
2 \\
3\end{array}$ & $\begin{array}{l}-\quad \mathrm{e} \\
- \\
-\end{array}$ & $\begin{array}{l}- \\
- \\
-\end{array}$ & $\begin{array}{l}- \\
\pm \\
-\end{array}$ & $\begin{array}{l}- \\
\pm \\
-\end{array}$ & $\begin{array}{l}- \\
- \\
-\end{array}$ & 1 & $\begin{array}{l}27 \\
28 \\
29\end{array}$ & $\begin{array}{l}- \\
- \\
-\end{array}$ & $\begin{array}{l} \pm \\
\pm \\
+\end{array}$ & $\begin{array}{l} \pm \\
\pm \\
-\end{array}$ & $\begin{array}{l}- \\
\pm \\
-\end{array}$ & $\begin{array}{l}- \\
- \\
-\end{array}$ \\
\hline 6 & $\begin{array}{l}4 \\
5 \\
6\end{array}$ & $\begin{array}{l}- \\
- \\
-\end{array}$ & $\begin{array}{l} \pm \\
\pm \\
\pm\end{array}$ & $\begin{array}{l} \pm \\
- \\
-\end{array}$ & $\begin{array}{l} \pm \\
\pm \\
\pm\end{array}$ & $\begin{array}{l}- \\
- \\
-\end{array}$ & 2 & $\begin{array}{l}30 \\
31 \\
32\end{array}$ & $\begin{array}{l}- \\
- \\
-\end{array}$ & $\begin{array}{l} \pm \\
\pm \\
\pm\end{array}$ & $\begin{array}{l}- \\
- \\
-\end{array}$ & $\begin{array}{l} \pm \\
- \\
-\end{array}$ & $\begin{array}{l}- \\
- \\
-\end{array}$ \\
\hline 7 & $\begin{array}{l}7 \\
8 \\
9\end{array}$ & $\begin{array}{l} \pm \\
- \\
-\end{array}$ & $\begin{array}{l} \pm \\
\pm \\
\pm\end{array}$ & $\begin{array}{l}+ \\
+ \\
+\end{array}$ & $\begin{array}{l} \pm \\
\pm \\
\pm\end{array}$ & $\begin{array}{l}- \\
- \\
-\end{array}$ & 3 & $\begin{array}{l}33 \\
34 \\
35\end{array}$ & $\begin{array}{l}- \\
- \\
-\end{array}$ & $\begin{array}{l} \pm \\
\pm \\
\pm\end{array}$ & $\begin{array}{l} \pm \\
+ \\
\pm\end{array}$ & $\begin{array}{l} \pm \\
\pm \\
-\end{array}$ & $\begin{array}{l}- \\
- \\
-\end{array}$ \\
\hline 8 & $\begin{array}{l}10 \\
11 \\
12\end{array}$ & $\begin{array}{l}- \\
- \\
-\end{array}$ & $\begin{array}{l} \pm \\
\pm \\
\pm\end{array}$ & $\begin{array}{l} \pm \\
\pm \\
\pm\end{array}$ & $\begin{array}{l}- \\
- \\
-\end{array}$ & $\begin{array}{l}- \\
- \\
-\end{array}$ & 4 & $\begin{array}{l}36 \\
37 \\
38\end{array}$ & $\begin{array}{l}- \\
- \\
-\end{array}$ & $\begin{array}{l}+ \\
+ \\
+\end{array}$ & $\begin{array}{l} \pm \\
+ \\
+\end{array}$ & $\begin{array}{l}- \\
\pm \\
\pm\end{array}$ & $\begin{array}{l}+ \\
+ \\
\pm\end{array}$ \\
\hline 10 & $\begin{array}{l}13 \\
14 \\
15 \\
16 \\
17\end{array}$ & $\begin{array}{l}- \\
- \\
- \\
- \\
-\end{array}$ & $\begin{array}{l}+ \\
\pm \\
\pm \\
+ \\
+\end{array}$ & $\begin{array}{l} \pm \\
- \\
- \\
- \\
-\end{array}$ & $\begin{array}{l} \pm \\
\pm \\
- \\
- \\
\pm\end{array}$ & $\begin{array}{l}- \\
- \\
- \\
\pm \\
+\end{array}$ & 6 & $\begin{array}{l}39 \\
40 \\
41\end{array}$ & $\begin{array}{l}- \\
- \\
-\end{array}$ & $\begin{array}{l}+ \\
\pm \\
\pm\end{array}$ & $\begin{array}{l} \pm \\
\pm \\
\pm\end{array}$ & $\begin{array}{l} \pm \\
\pm \\
\pm\end{array}$ & $\begin{array}{l} \pm \\
- \\
-\end{array}$ \\
\hline 12 & $\begin{array}{l}18 \\
19 \\
20\end{array}$ & $\begin{array}{l} \pm \\
- \\
-\end{array}$ & $\begin{array}{l} \pm \\
\pm \\
\pm\end{array}$ & $\begin{array}{l} \pm \\
\pm \\
-\end{array}$ & $\begin{array}{l} \pm \\
\pm \\
-\end{array}$ & $\begin{array}{l} \pm \\
\pm \\
-\end{array}$ & 8 & $\begin{array}{l}42 \\
43 \\
44\end{array}$ & $\begin{array}{l}- \\
- \\
-\end{array}$ & $\begin{array}{l} \pm \\
+ \\
+\end{array}$ & $\begin{array}{l} \pm \\
\pm \\
-\end{array}$ & $\begin{array}{l} \pm \\
\pm \\
\pm\end{array}$ & $\begin{array}{l}- \\
- \\
-\end{array}$ \\
\hline 14 & $\begin{array}{l}21 \\
22 \\
23\end{array}$ & $\begin{array}{l}- \\
- \\
-\end{array}$ & $\begin{array}{l} \pm \\
\pm \\
\pm\end{array}$ & $\begin{array}{l}- \\
- \\
-\end{array}$ & $\begin{array}{l}+ \\
+ \\
\pm\end{array}$ & $\begin{array}{l} \pm \\
- \\
\pm\end{array}$ & 10 & $\begin{array}{l}45 \\
46 \\
47\end{array}$ & $\begin{array}{l} \pm \\
- \\
\pm\end{array}$ & $\begin{array}{l}\oplus \\
+ \\
\oplus\end{array}$ & $\begin{array}{l}- \\
\pm \\
-\end{array}$ & $\begin{array}{l}+ \\
\pm \\
\pm\end{array}$ & $\begin{array}{l}\oplus \\
\oplus \\
\oplus\end{array}$ \\
\hline 16 & $\begin{array}{l}24 \\
25 \\
26\end{array}$ & $\begin{array}{l} \pm \\
\pm \\
-\end{array}$ & $\begin{array}{l} \pm \\
+ \\
\pm\end{array}$ & $\begin{array}{l}- \\
- \\
\pm\end{array}$ & $\begin{array}{l}+ \\
\oplus \\
\pm\end{array}$ & $\begin{array}{l}- \\
-\end{array}$ & 12 & $\begin{array}{l}48 \\
49 \\
50\end{array}$ & $\begin{array}{l}- \\
- \\
-\end{array}$ & $\begin{array}{l} \pm \\
\pm \\
\pm\end{array}$ & $\begin{array}{l} \pm \\
\pm \\
\pm\end{array}$ & $\begin{array}{l} \pm \\
- \\
-\end{array}$ & $\begin{array}{l} \pm \\
+ \\
-\end{array}$ \\
\hline & & & & & & & 22 & $\begin{array}{l}51 \\
52 \\
53\end{array}$ & $\begin{array}{l}- \\
- \\
-\end{array}$ & $\begin{array}{l}+ \\
+ \\
+\end{array}$ & $\begin{array}{l}+ \\
\pm \\
\pm\end{array}$ & $\begin{array}{l} \pm \\
\pm \\
-\end{array}$ & $\begin{array}{l}+ \\
+ \\
+\end{array}$ \\
\hline
\end{tabular}

a 4 か月間飲料水で飼育後, 継続して飲料水で飼育

b 空胞形成：脂肪滴を含む腺細胞実質の空胞構造

c 脂肪変性：脂肪組織による腺実質の置換

d 4 か月間领料水で飼育後エタノールで飼育

$\mathrm{e} \oplus$ 高度変化, 十中等度変化, 土軽度変化, 一無変化 
表 4 介在部導管の光顕的所見

\begin{tabular}{|c|c|c|c|c|c|c|c|c|c|c|c|}
\hline \multicolumn{6}{|c|}{ 対 照 群 } & \multicolumn{6}{|c|}{ エタノール群 } \\
\hline $\begin{array}{c}\text { 飼 } \\
\text { 能 } \\
\text { 期 } \\
\text { 間 } \\
\mathrm{a}\end{array}$ & $\begin{array}{c}\text { ラ } \\
\% \\
\text { r } \\
\mathrm{N} 0\end{array}$ & 桩 & 狭 & 增 & $\begin{array}{l}\text { 眝 } \\
\text { 溜 } \\
\text { 物 }\end{array}$ & $\begin{array}{c}\text { 投 } \\
\text { 与 } \\
\text { 期 } \\
\text { 間 } \\
\text { b }\end{array}$ & $\begin{array}{c}\text { ラ } \\
\% \\
\text { 卜 } \\
\text { NQ }\end{array}$ & 桩 & 狭 & 增 & $\begin{array}{l}\text { 眝 } \\
\text { 溜 } \\
\text { 物 }\end{array}$ \\
\hline 5 & $\begin{array}{l}1 \\
2 \\
3\end{array}$ & $\begin{array}{l}- \\
- \\
-\end{array}$ & $\begin{array}{l}- \\
-\end{array}$ & $\begin{array}{l}- \\
- \\
-\end{array}$ & $\begin{array}{l}+ \\
-\end{array}$ & 1 & $\begin{array}{l}27 \\
28 \\
29\end{array}$ & $\begin{array}{l}- \\
-\end{array}$ & $\begin{array}{l} \pm \\
\pm \\
-\end{array}$ & $\begin{array}{l}- \\
\pm \\
-\end{array}$ & $\begin{array}{l}- \\
-\end{array}$ \\
\hline 6 & $\begin{array}{l}4 \\
5 \\
6\end{array}$ & $\begin{array}{l}- \\
- \\
-\end{array}$ & $\begin{array}{l}- \\
- \\
-\end{array}$ & $\begin{array}{l}- \\
- \\
-\end{array}$ & $\begin{array}{l}- \\
-\end{array}$ & 2 & $\begin{array}{l}30 \\
31 \\
32\end{array}$ & $\begin{array}{l}- \\
\pm \\
-\end{array}$ & $\begin{array}{l}- \\
- \\
-\end{array}$ & $\begin{array}{l}- \\
- \\
-\end{array}$ & $\begin{array}{l}- \\
-\end{array}$ \\
\hline 7 & $\begin{array}{l}7 \\
8 \\
9\end{array}$ & $\begin{array}{l}- \\
- \\
-\end{array}$ & $\begin{array}{l} \pm \\
- \\
-\end{array}$ & $\begin{array}{l}- \\
- \\
-\end{array}$ & $\begin{array}{l}- \\
- \\
-\end{array}$ & 3 & $\begin{array}{l}33 \\
34 \\
35\end{array}$ & $\begin{array}{l}- \\
- \\
-\end{array}$ & $\begin{array}{l}- \\
- \\
-\end{array}$ & $\begin{array}{l}- \\
\pm \\
-\end{array}$ & $\begin{array}{l}- \\
- \\
-\end{array}$ \\
\hline 8 & $\begin{array}{l}10 \\
11 \\
12\end{array}$ & $\begin{array}{l}- \\
- \\
-\end{array}$ & $\begin{array}{l}- \\
- \\
-\end{array}$ & $\begin{array}{l}- \\
- \\
-\end{array}$ & $\begin{array}{l}- \\
- \\
-\end{array}$ & 4 & $\begin{array}{l}36 \\
37 \\
38\end{array}$ & $\begin{array}{l} \pm \\
\pm \\
\pm\end{array}$ & $\begin{array}{l}- \\
- \\
-\end{array}$ & $\begin{array}{l}+ \\
\pm \\
+\end{array}$ & $\begin{array}{l}- \\
- \\
-\end{array}$ \\
\hline 10 & $\begin{array}{l}13 \\
14 \\
15 \\
16 \\
17\end{array}$ & $\begin{array}{l}- \\
- \\
- \\
- \\
-\end{array}$ & $\begin{array}{l}- \\
- \\
- \\
- \\
-\end{array}$ & $\begin{array}{l}- \\
- \\
- \\
- \\
-\end{array}$ & $\begin{array}{l}- \\
- \\
- \\
- \\
\pm\end{array}$ & 6 & $\begin{array}{l}39 \\
40 \\
41\end{array}$ & $\begin{array}{l} \pm \\
\pm \\
\pm\end{array}$ & $\begin{array}{l}- \\
- \\
-\end{array}$ & $\begin{array}{l}- \\
\pm \\
\pm\end{array}$ & $\begin{array}{l}- \\
-\end{array}$ \\
\hline 12 & $\begin{array}{l}18 \\
19 \\
20\end{array}$ & $\begin{array}{l} \pm \\
- \\
-\end{array}$ & $\begin{array}{l}- \\
- \\
-\end{array}$ & $\begin{array}{l} \pm \\
- \\
-\end{array}$ & $\begin{array}{l}- \\
- \\
-\end{array}$ & 8 & $\begin{array}{l}42 \\
43 \\
44\end{array}$ & $\begin{array}{l} \pm \\
\pm \\
\pm\end{array}$ & $\begin{array}{l}- \\
- \\
-\end{array}$ & $\begin{array}{l} \pm \\
\pm \\
\pm\end{array}$ & $\begin{array}{l}- \\
- \\
\pm\end{array}$ \\
\hline 14 & $\begin{array}{l}21 \\
22 \\
23\end{array}$ & $\begin{array}{l}- \\
\pm \\
-\end{array}$ & $\begin{array}{l}- \\
-\end{array}$ & $\begin{array}{l}- \\
- \\
-\end{array}$ & $\begin{array}{l}- \\
- \\
-\end{array}$ & 10 & $\begin{array}{l}45 \\
46 \\
47\end{array}$ & $\begin{array}{l}\oplus \\
\oplus \\
\pm\end{array}$ & $\begin{array}{l}- \\
+ \\
-\end{array}$ & $\begin{array}{l}\oplus \\
+ \\
+\end{array}$ & $\begin{array}{l}- \\
-\end{array}$ \\
\hline 16 & $\begin{array}{l}24 \\
25 \\
26\end{array}$ & $\begin{array}{l} \pm \\
+ \\
-\end{array}$ & $\begin{array}{l}- \\
- \\
-\end{array}$ & $\begin{array}{l}- \\
\pm \\
-\end{array}$ & $\begin{array}{l}- \\
- \\
-\end{array}$ & 12 & $\begin{array}{l}48 \\
49 \\
50\end{array}$ & $\begin{array}{l} \pm \\
- \\
-\end{array}$ & $\begin{array}{l}- \\
- \\
-\end{array}$ & $\begin{array}{l} \pm \\
- \\
-\end{array}$ & $\begin{array}{l}- \\
-\end{array}$ \\
\hline & & & & & & 22 & $\begin{array}{l}51 \\
52 \\
53\end{array}$ & $\begin{array}{l}+ \\
+ \\
-\end{array}$ & $\begin{array}{l}- \\
- \\
-\end{array}$ & $\begin{array}{l}- \\
\pm \\
\pm\end{array}$ & $\begin{array}{l}- \\
- \\
+\end{array}$ \\
\hline
\end{tabular}

a , b , c 表 3 を参照

腺房部や介在部に比べて線条部においては，導管の拡 張や増生といった光影上の変化は少なかった。

管腔には対照群に拈いてもエタノール群においても初 期から貯溜物が認められるが，ともに経時的変化はなか った。

\section{3. 電顕的所見}

1) 腺房細胞

腺房細胞の電顕的所見の概要を表 6 に示した.

耳下腺組織全体に対する腺房部の占める割合がェタ， 一ル投与 6 か月以後に減少し，一細胞あたりの分泌顆粒 も減少する傾向を示した。分泌顆粒には, 高電子密度で 
表 5 線条部導管の光顕的所見

\begin{tabular}{|c|c|c|c|c|c|c|c|c|c|c|c|}
\hline \multicolumn{6}{|c|}{ 対 照 群 } & \multicolumn{6}{|c|}{ エタノール群 } \\
\hline $\begin{array}{c}\text { 食司 } \\
\text { 䏍 } \\
\text { 期 } \\
\text { 間 } \\
\text { a }\end{array}$ & $\begin{array}{c}\text { ラ } \\
\% \\
\text { ト } \\
\text { No. }\end{array}$ & $\begin{array}{l}\text { 桩 } \\
\text { 張 }\end{array}$ & 狭 & $\begin{array}{l}\text { 增 } \\
\text { 生 }\end{array}$ & $\begin{array}{l}\text { 貯 } \\
\text { 溜 } \\
\text { 物 }\end{array}$ & $\begin{array}{c}\text { 投 } \\
\text { 与 } \\
\text { 期 } \\
\text { 間 } \\
\text { b }\end{array}$ & $\begin{array}{c}\text { ラ } \\
\text { \% } \\
\text { 卜 } \\
\mathrm{N} 0 .\end{array}$ & 拻 & 狭 & 增 & $\begin{array}{l}\text { 貯 } \\
\text { 溜 } \\
\text { 物 }\end{array}$ \\
\hline 5 & $\begin{array}{l}1 \\
2 \\
3\end{array}$ & $\begin{array}{l}- \\
- \\
-\end{array}$ & $\begin{array}{l}- \\
- \\
-\end{array}$ & $\begin{array}{l}- \\
- \\
-\end{array}$ & $\begin{array}{l}+ \\
+ \\
\pm\end{array}$ & 1 & $\begin{array}{l}27 \\
28 \\
29\end{array}$ & $\begin{array}{l}- \\
- \\
-\end{array}$ & $\begin{array}{l} \pm \\
- \\
-\end{array}$ & $\begin{array}{l}- \\
- \\
-\end{array}$ & $\begin{array}{l}- \\
\pm \\
\pm\end{array}$ \\
\hline 6 & $\begin{array}{l}4 \\
5 \\
6\end{array}$ & $\begin{array}{l}- \\
- \\
-\end{array}$ & $\begin{array}{l}- \\
-\end{array}$ & $\begin{array}{l}- \\
- \\
-\end{array}$ & $\begin{array}{l}- \\
+ \\
+\end{array}$ & 2 & $\begin{array}{l}30 \\
31 \\
32\end{array}$ & $\begin{array}{l}- \\
- \\
-\end{array}$ & $\begin{array}{l} \pm \\
\pm \\
-\end{array}$ & $\begin{array}{l}- \\
-\end{array}$ & $\begin{array}{l} \pm \\
\pm \\
-\end{array}$ \\
\hline 7 & $\begin{array}{l}7 \\
8 \\
9\end{array}$ & $\begin{array}{l}- \\
- \\
-\end{array}$ & $\begin{array}{l}- \\
- \\
-\end{array}$ & $\begin{array}{l}- \\
- \\
-\end{array}$ & $\begin{array}{l}- \\
-\end{array}$ & 3 & $\begin{array}{l}33 \\
34 \\
35\end{array}$ & $\begin{array}{l}- \\
- \\
-\end{array}$ & $\begin{array}{l}- \\
- \\
-\end{array}$ & $\begin{array}{l}- \\
- \\
-\end{array}$ & $\begin{array}{l}+ \\
- \\
\pm\end{array}$ \\
\hline 8 & $\begin{array}{l}10 \\
11 \\
12\end{array}$ & $\begin{array}{l}- \\
- \\
-\end{array}$ & $\begin{array}{l}- \\
-\end{array}$ & $\begin{array}{l}- \\
- \\
-\end{array}$ & $\begin{array}{l}- \\
\pm \\
\pm\end{array}$ & 4 & $\begin{array}{l}36 \\
37 \\
38\end{array}$ & $\begin{array}{l}- \\
- \\
-\end{array}$ & $\begin{array}{l}- \\
-\end{array}$ & $\begin{array}{l} \pm \\
- \\
-\end{array}$ & $\begin{array}{l} \pm \\
\pm \\
\pm\end{array}$ \\
\hline 10 & $\begin{array}{l}13 \\
14 \\
15 \\
16 \\
17\end{array}$ & $\begin{array}{l}- \\
- \\
- \\
-\end{array}$ & $\begin{array}{l} \pm \\
- \\
- \\
-\end{array}$ & $\begin{array}{l}- \\
- \\
- \\
-\end{array}$ & $\begin{array}{l}+ \\
\pm \\
\pm \\
+ \\
-\end{array}$ & 6 & $\begin{array}{l}39 \\
40 \\
41\end{array}$ & $\begin{array}{l}- \\
- \\
-\end{array}$ & $\begin{array}{l}- \\
- \\
-\end{array}$ & $\begin{array}{l}- \\
- \\
-\end{array}$ & $\begin{array}{l}- \\
- \\
-\end{array}$ \\
\hline 12 & $\begin{array}{l}18 \\
19 \\
20\end{array}$ & $\begin{array}{l}- \\
- \\
-\end{array}$ & $\begin{array}{l}- \\
-\end{array}$ & $\begin{array}{l}- \\
- \\
-\end{array}$ & $\begin{array}{l} \pm \\
- \\
-\end{array}$ & 8 & $\begin{array}{l}42 \\
43 \\
44\end{array}$ & $\begin{array}{l}- \\
- \\
-\end{array}$ & $\begin{array}{l}- \\
-\end{array}$ & $\begin{array}{l}- \\
- \\
-\end{array}$ & $\begin{array}{l}- \\
\pm \\
+\end{array}$ \\
\hline 14 & $\begin{array}{l}21 \\
22 \\
23\end{array}$ & $\begin{array}{l}- \\
- \\
-\end{array}$ & $\begin{array}{l}- \\
- \\
-\end{array}$ & $\begin{array}{l}- \\
- \\
-\end{array}$ & $\begin{array}{l} \pm \\
\pm \\
\pm\end{array}$ & 10 & $\begin{array}{l}45 \\
46 \\
47\end{array}$ & $\begin{array}{l}- \\
- \\
-\end{array}$ & $\begin{array}{l}- \\
+ \\
\pm\end{array}$ & $\begin{array}{l}- \\
- \\
-\end{array}$ & $\begin{array}{l} \pm \\
\pm \\
-\end{array}$ \\
\hline 16 & $\begin{array}{l}24 \\
25 \\
26\end{array}$ & $\begin{array}{l}- \\
- \\
-\end{array}$ & $\begin{array}{l}- \\
-\end{array}$ & $\begin{array}{l}- \\
\pm \\
-\end{array}$ & $\begin{array}{l}- \\
+ \\
-\end{array}$ & 12 & $\begin{array}{l}48 \\
49 \\
50\end{array}$ & $\begin{array}{l}- \\
- \\
-\end{array}$ & $\begin{array}{l}- \\
- \\
-\end{array}$ & $\begin{array}{l}- \\
-\end{array}$ & $\begin{array}{l}- \\
+ \\
-\end{array}$ \\
\hline & & & & & & 22 & $\begin{array}{l}51 \\
52 \\
53\end{array}$ & $\begin{array}{l}- \\
- \\
+\end{array}$ & $\begin{array}{l}- \\
- \\
-\end{array}$ & \pm & $\begin{array}{l} \pm \\
- \\
+\end{array}$ \\
\hline
\end{tabular}

$\mathrm{a}, \mathrm{b}, \mathrm{c}$ 表 3 を参照

不均質な顆粒と低電子密度で均質な顆粒がみられ（写真

2), 後者は対照群では飼育 12 か月以後に一部にみられ ただけであるが，エタノール群ではェタノール投与 3 か 月以後に頻繁にみられた。

ミトコンドリアではェタノール群に 2 種類の变化が観 察された。ひとつは淡明な基質を伴らクリスタの減少
で，ェタノール投与 6 か月以後に高い頻度で出現した。 他は暗い基質を伴らクリスタの減少で、これはェタノ一 ル投与 6 か月のラット1匹のみに認められた。ミトコン ドリアの数の增減はほとんどなかったが，大小不動の傾 向がェタノール投与 6 か月頃から認められた。

小胞体の内腔払張はエタノール群に批いて初期から軽 
表 6 腺房細胞の電顕的所見

\begin{tabular}{|c|c|c|c|c|c|c|c|c|c|c|c|c|c|c|c|}
\hline \multicolumn{8}{|c|}{ 対 照 群 } & \multicolumn{8}{|c|}{ エタノール群 } \\
\hline \multirow{3}{*}{$\begin{array}{l}\text { 飼 } \\
\text { 育 }\end{array}$} & \multirow[t]{2}{*}{ ラ } & \multirow{8}{*}{$\begin{array}{l}\Sigma \\
ト \\
\beth \\
ン \\
ト ゙ \\
リ \\
\supset\end{array}$} & & & \multirow{8}{*}{$\begin{array}{l}\text { 粗 } \\
\text { 面 } \\
\text { 小 } \\
\text { 胞 } \\
\text { 体 } \\
\text { の } \\
\text { 扗 } \\
\text { 張 }\end{array}$} & \multirow{8}{*}{$\begin{array}{l}\text { ラ } \\
1 \\
y \\
y \\
1 \\
厶 \\
\text { の } \\
\text { 増 } \\
\text { 加 }\end{array}$} & \multirow{8}{*}{$\begin{array}{l}\text { 腺 } \\
\text { 房 } \\
\text { 紐 } \\
\text { 胞 } \\
\text { 間 } \\
\text { の } \\
\text { 嵌 } \\
\text { 合 }\end{array}$} & \multirow{8}{*}{$\begin{array}{c}\text { 投 } \\
\text { 与 } \\
\text { 期 } \\
\text { 間 } \\
\text { b }\end{array}$} & \multirow{3}{*}{ ラ } & \multirow{2}{*}{ ミ } & \multirow[b]{2}{*}{$\eta$} & \multirow[b]{2}{*}{ 暗 } & \multirow{8}{*}{$\begin{array}{l}\text { 粗 } \\
\text { 面 } \\
\text { 小 } \\
\text { 胞 } \\
\text { 体 } \\
\text { の } \\
\text { 拡 } \\
\text { 張 }\end{array}$} & \multirow{8}{*}{$\begin{array}{l}\text { ラ } \\
1 \\
\text { y } \\
\text { ソ } \\
1 \\
厶 \\
\text { の } \\
\text { 增 } \\
\text { 加 }\end{array}$} & \multirow{8}{*}{$\begin{array}{c}\text { 腺 } \\
\text { 房 } \\
\text { 細 } \\
\text { 胞 } \\
\text { 間 } \\
\text { の } \\
\text { 嵌 } \\
\text { 合 }\end{array}$} \\
\hline & & & ク & 暗 & & & & & & & & & & & \\
\hline & ッ & & リ & & & & & & & ב & リ & & & & \\
\hline 期 & & & 人 & い & & & & & & ช & ス & い & & & \\
\hline Fo子 & r & & タ & & & & & & r & 5 & タ & & & & \\
\hline 間 & & & の & 基 & & & & & $r$ & ド & の & 基 & & & \\
\hline & & & 減 & & & & & & & リ & 隇 & & & & \\
\hline a & $\mathrm{NQ}$ & & 少 & 質 & & & & & $\mathrm{Na}$ & ア & 少 & 質 & & & \\
\hline \multirow{3}{*}{5} & 1 & & - & - & - & \pm & \pm & & 27 & & - & - & - & \pm & + \\
\hline & 2 & & - & - & - & \pm & - & 1 & 28 & & - & - & \pm & \pm & \pm \\
\hline & 3 & & - & - & - & \pm & - & & 29 & & - & - & \pm & + & \pm \\
\hline \multirow{6}{*}{6} & 4 & & - & - & \pm & \pm & \pm & & 30 & & - & - & \pm & \pm & \pm \\
\hline & 5 & & - & - & - & \pm & - & 2 & 31 & & \pm & - & + & \pm & \pm \\
\hline & 6 & & - & - & - & \pm & - & & & & & & & & \\
\hline & & & & & & & & & 33 & & - & - & - & \pm & + \\
\hline & & & & & & & & 3 & 34 & & - & - & + & \pm & + \\
\hline & & & & & & & & & 35 & & - & - & \pm & \pm & + \\
\hline \multirow{3}{*}{8} & 10 & & - & - & - & \pm & - & & 36 & & - & - & \pm & + & + \\
\hline & 11 & & - & - & - & \pm & - & 4 & 37 & & - & - & \pm & + & \pm \\
\hline & 12 & & - & - & - & \pm & - & & 38 & & - & - & \pm & + & \pm \\
\hline \multirow{13}{*}{10} & 14 & & - & - & - & \pm & - & & 39 & & \pm & - & - & \pm & \pm \\
\hline & 15 & & - & - & - & - & \pm & 6 & 40 & & \pm & \pm & \pm & + & + \\
\hline & & & & & & & & & 41 & & \pm & - & \pm & + & \pm \\
\hline & & & & & & & & & 42 & & \pm & - & - & - & \pm \\
\hline & & & & & & & & 8 & 43 & & \pm & - & + & \pm & + \\
\hline & & & & & & & & 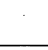 & 44 & & \pm & - & \pm & \pm & \pm \\
\hline & & & & & & & & & 45 & & - & - & \pm & \pm & + \\
\hline & & & & & & & & 10 & 46 & & - & - & + & + & + \\
\hline & & & & & & & & & 47 & & - & - & - & \pm & + \\
\hline & & & & & & & & 12 & 48 & & + & - & \pm & + & + \\
\hline & & & & & & & & & 49 & & + & - & \pm & + & + \\
\hline & & & & & & & & 22 & 51 & & + & - & + & \pm & + \\
\hline & & & & & & & & & 52 & & + & - & + & \pm & + \\
\hline
\end{tabular}

a， b , c 表 3 を参照

度に增加したが経時的变動は著明にはみられなかった。 またライソゾームと脂肪滴を含む空胞構造もェタノール 群において初期からみられたが，これは対照群において もみられ，両群の間に大差はなかった。

2) 介在部導管

介在部導管の電顕的所見の概要を表 7 に示した。

介在部導管における著明な変化は, 核数の增加を伴う 增生であった。この所見はェタノール投与 4 か月以後に
高頻度にみられた（写真 3）。

介在部導管細胞の PAS 陽性顆粒は, 電子密度が高く 腺房細胞の分泌顆粒よりやや小型で均質であった。 その 数は腺房細胞の分泌顆粒より少なく管腔側に偏在してい た（写真 4 ）。この顆粒はェタノール投与による変化は とくに示さなかった。

ミトコンドリアはェタノール投与 3 か月目からわずか に膨化する傾向や, 淡明な基質を伴らクリスタの減少が 
表 7 介在部導管の電頙的所先

\begin{tabular}{|c|c|c|c|c|c|c|c|c|c|c|c|c|c|c|c|}
\hline \multicolumn{8}{|c|}{ 対＼cjkstart照＼cjkstart群 } & \multicolumn{8}{|c|}{ エタノール群 } \\
\hline \multirow{2}{*}{$\begin{array}{l}\text { 餇 } \\
\text { 奋 }\end{array}$} & \multirow{2}{*}{ ラ } & \multirow{7}{*}{ 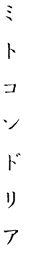 } & \multirow{7}{*}{$\begin{array}{l}\text { ク } \\
\text { リ } \\
\text { 久 } \\
\text { 夕 } \\
\text { の } \\
\text { 減 } \\
\text { 少 }\end{array}$} & \multirow[b]{2}{*}{ 喑 } & \multirow{7}{*}{ 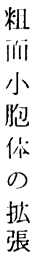 } & \multirow{7}{*}{$\begin{array}{l}\text { F } \\
1 \\
y \\
y \\
1 \\
厶 \\
\sigma \\
\text { 出 } \\
\text { 增 } \\
\text { 加 }\end{array}$} & \multirow[t]{2}{*}{ 㤥 } & \multirow[t]{2}{*}{ 技 } & \multirow[t]{2}{*}{ ラ } & $\Sigma$ & \multirow[b]{2}{*}{$ク$} & \multirow[b]{2}{*}{ 暗 } & \multirow{2}{*}{$\begin{array}{l}\text { 粗 } \\
\text { 面ii }\end{array}$} & \multirow{2}{*}{$\begin{array}{l}\text { ラ } \\
\text { 1 }\end{array}$} & \multirow{2}{*}{ 核 } \\
\hline & & & & & & & & & & 卜 & & & & & \\
\hline & " & & & 1 & & & の) & IJ. & " & 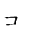 & リ) & & & $\%$ & の \\
\hline 灲 & & & & 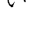 & & & & 渋 & & ソ & 2 & い & 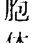 & 1 & \\
\hline $14^{4}$ & 卜 & & & 基 & & & 增 & II & r & ト & の) & 基 & $\begin{array}{l}\text { 14 } \\
\text { ⿹ }\end{array}$ & $\Delta$ & 增 \\
\hline (Fil] & & & & & & & & (Fi) & & リ & 減 & & 抬 & 增 & \\
\hline a & $\mathrm{Na}$ & & & 質 & & & 加 & $\mathrm{b}$ & $\mathrm{Na}$ & $\boldsymbol{P}$ & 少 & 質 & 張 & 加 & 加 \\
\hline \multirow{3}{*}{5} & 1 & & $-c$ & - & - & \pm & - & \multirow{3}{*}{1} & 27 & & - & - & - & \pm & - \\
\hline & 2 & & - & - & - & \pm & - & & 28 & & - & - & - & \pm & - \\
\hline & 3 & & - & - & - & - & - & & 29 & & - & - & - & \pm & \pm \\
\hline \multirow{6}{*}{6} & 4 & & - & - & \pm & - & - & \multirow{3}{*}{2} & 30 & & - & - & - & \pm & - \\
\hline & 5 & & - & - & - & - & - & & 31 & & - & - & \pm & \pm & - \\
\hline & 6 & & - & - & - & - & - & & & & & & & & \\
\hline & & & & & & & & & 33 & & - & - & + & - & - \\
\hline & & & & & & & & 3 & 34 & & \pm & - & \pm & \pm & \pm \\
\hline & & & & & & & & & 35 & & - & - & \pm & - & - \\
\hline \multirow{3}{*}{8} & 10 & & - & - & - & - & - & \multirow{3}{*}{4} & 36 & & \pm & - & \pm & \pm & + \\
\hline & 11 & & - & - & - & - & - & & 37 & & \pm & \pm & + & \pm & \pm \\
\hline & 12 & & - & - & - & \pm & - & & 38 & & \pm & - & \pm & + & + \\
\hline \multirow{13}{*}{10} & 14 & & - & - & - & - & - & & 39 & & \pm & - & \pm & \pm & - \\
\hline & 15 & & - & - & - & - & - & 6 & 40 & & \pm & - & \pm & \pm & \pm \\
\hline & & & & & & & & & 41 & & \pm & - & \pm & \pm & \pm \\
\hline & & & & & & & & & 42 & & - & - & - & 土 & - \\
\hline & & & & & & & & 8 & 43 & & \pm & - & + & \pm & \pm \\
\hline & & & & & & & & & 44 & & - & - & \pm & \pm & \pm \\
\hline & & & & & & & & & 45 & & - & - & \pm & \pm & + \\
\hline & & & & & & & & 10 & 46 & & - & - & - & \pm & + \\
\hline & & & & & & & & & 47 & & - & - & - & \pm & + \\
\hline & & & & & & & & 12 & 48 & & - & - & - & + & \pm \\
\hline & & & & & & & & & 49 & & - & - & - & - & - \\
\hline & & & & & & & & 22 & 51 & & - & - & - & \pm & - \\
\hline & & & & & & & & 22 & 52 & & - & - & - & \pm & _ \\
\hline
\end{tabular}

a， b， c 表 3 t参熙

みられた。 また隌い基質を伴 5ミトフンドリアの変化 は，ェタノール投与 4 か月のラット1匹においてのみ認 められた。

小胞体の内腔払張や空胞形成は対照群ではほとんどみ られなかったが，エタノール群では初期から高頻度にみ られた。

\section{3 ）線条部導管}

線条部紫管の電顕的所見の概要を表 8 に示した。
線条部導管細胞には直径 $0.1 \sim 0.2 \mu$ 大の低電子密度 の顆粒状構造物が管腔側に認められた（写真 5 )。 その 数は個々の紐胞によりばらつきがあったが，エタノール 投与による变化は認められなかった。

対照群においては線条部導管紐胞の基底側では，基底 層の細胞質中への深い陷入楧造が艋数にみられ, それに 並行してミトコンドリアが存在していた。つまりミトコ ンドリアは基底側に偏在して钼察されたが（写真 6)， 


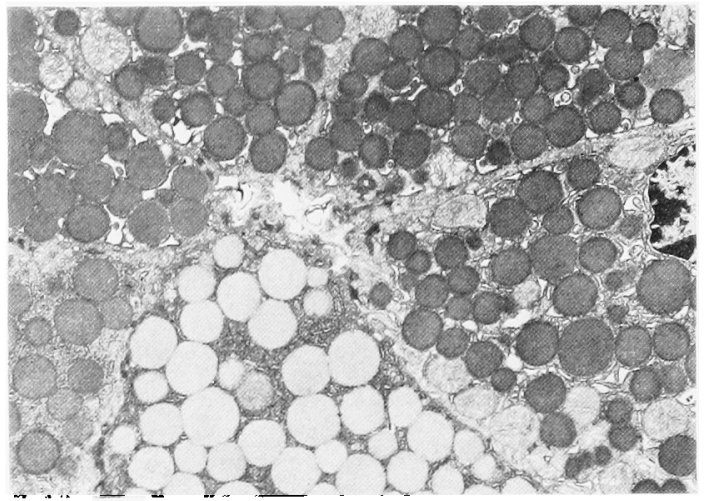

写真 2 ×タール群の電顕像・腺房細胞

（ラットNo. 37 上タール投与 4 か月）腺房部細 胞には高電子密度の顆粒と低電子密度の顆粒とが認 められる。

$\times 5,000$

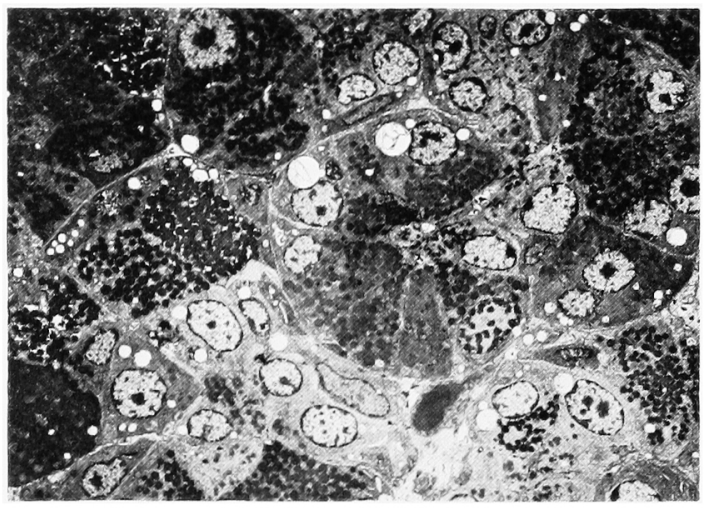

写真 $3 \simeq タ$ イール群の電䫓像

（ラットNo. 37 ェタノール投与 4 か月）核の増加 を伴 5 介在部導管細胞の增加が認められる。 $\times 1,000$

エタノ一ル群ではェタノール投与初期から管腔側への変 位が著明で基底側偘入满造の減少とあいまって線条構造 に乱れを生じていた。

また，腺房細胞や介在部導管細胞ではほとんどみられ なかった隌い基質とクリスタの隇少を示すミトコンドリ アも高頻度にみられた（写真 7).クリスタの減少は 24 匹中21匹 $(88 \%)$ K，隌い基質は 24 匹中 20 匹（83\%） にみられた。

淡明な基質を伴らミトコンドリアの変化はェタノール 投与期間や病菄の重篤度とは無関係にしばしば出現した か゚，腤い基質を伴らミトコンドリアの変化はエタノール 群に特有のものと考えられた。

エタノール投与10か月以後になると，線条部導管細胞 の崩畩が起こり，基底膜が不規則に重層して残存してい

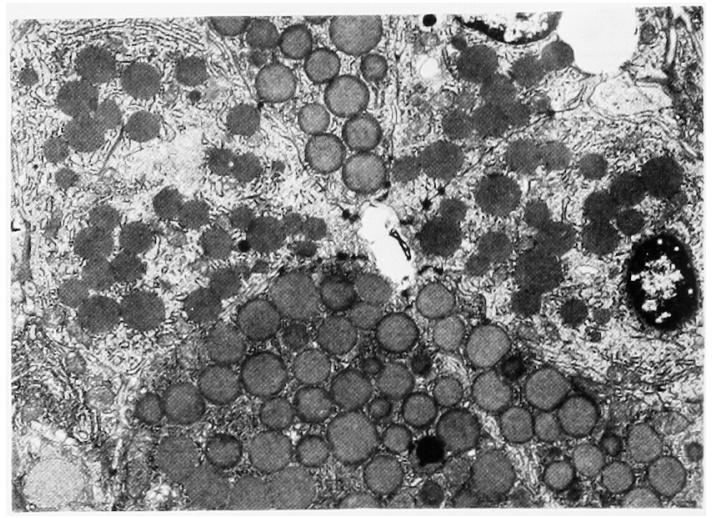

写真 4 対炤群の電䫓像・介在部導管 （ラットNo. 12 飼育期間 8 か月）介在部對管和胞 の管腔側に，電子密度の高い均質で小型の顆粒が認 められる。

$\times 5,000$

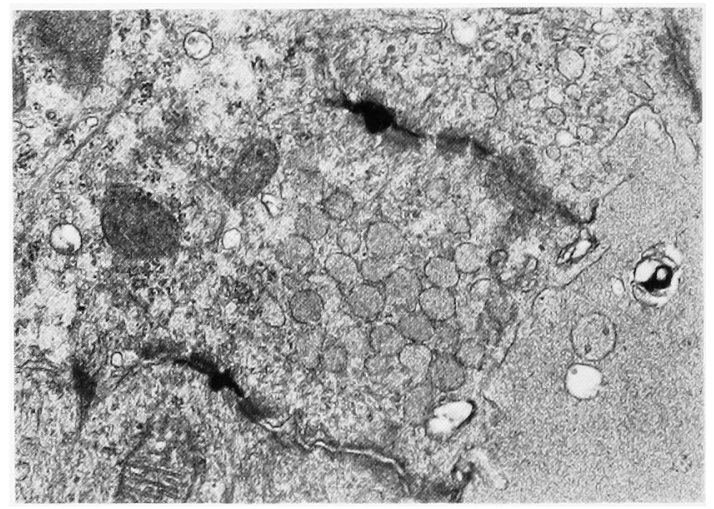

写真 5 対照群の電影像・線条部導管 (ラットNo. 5 飼育期問 6 か月) 線条部道管細胞管 腔側の電子密度の低い微小な顆粒状棈造物 $\times 20,000$

るのが認められた（写真 8).

4) 末梢神経・毛細血管

林梢神経と毛細血管の電顕的所見の概要を表 9 に示し た.

神経組織の变化としては軸索突起の膨化およびその内 部における autolysosome と考えられるミェリン像がェ タノール投与期間とは無関係に一部にみられた（写真 9).これらの傷害された軸索突起内のミトュンドリア の変化やミェりン䩤を含むシニワン細胞の変化はほとん ぞなかった、このよ5な神経組織の変化は 27 匹中 8 匹 (30\%)において観察された。

毛細血管では micropinocytotic vesicle の減少がェタ ノール投与 22 か月のラットで観察されたにすぎなかっ た. 
表 8 線条部導管の電顕的所見

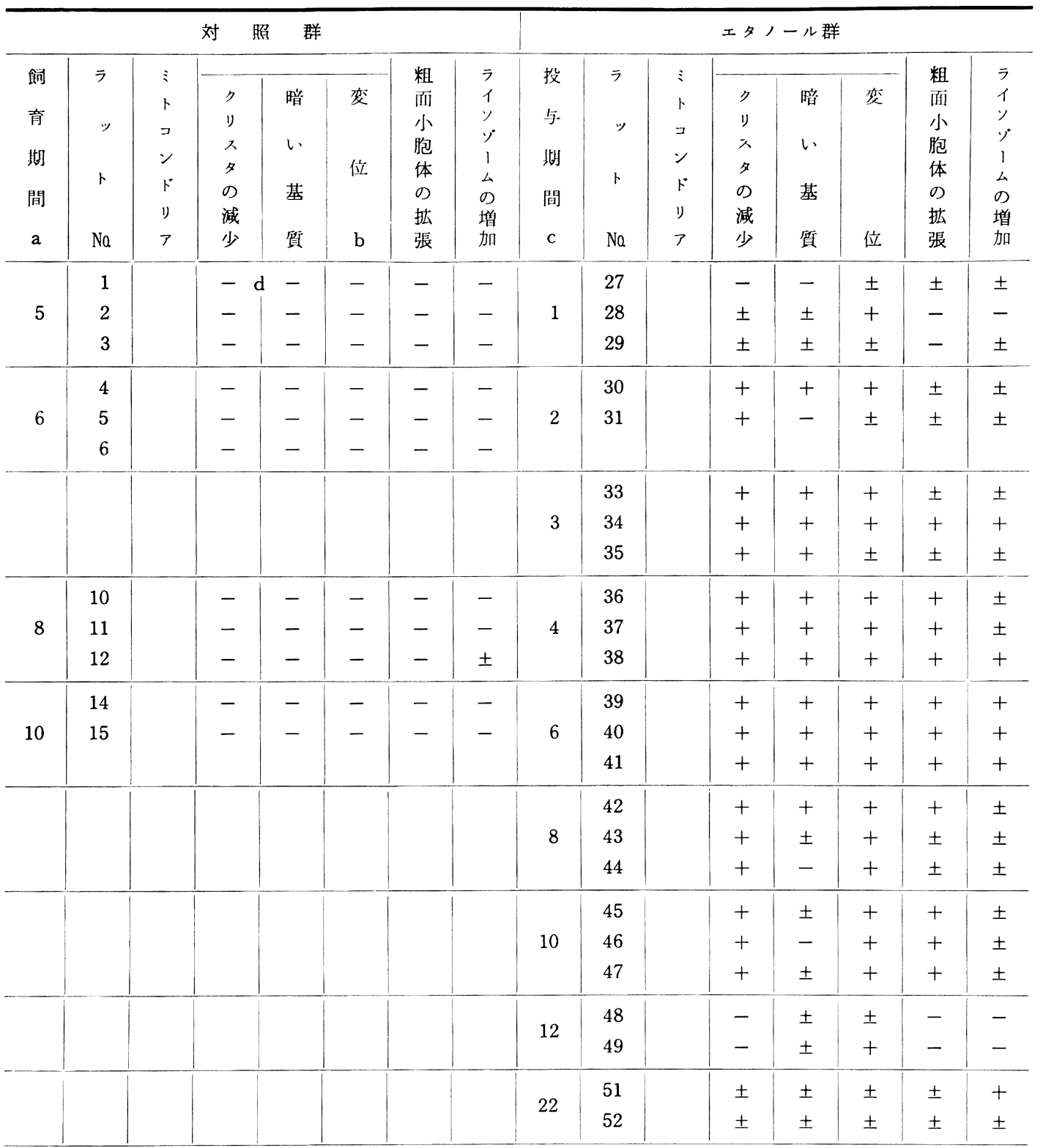

a ， b， c 表 3 を参照

b ミトコンドリアの基底側から管腔側への移動

5 ）細胞膜

対照群においては，腺房細胞の側面細胞膜の基底側に 近い部分で一部に軽度の茨合がみられた。これに対しェ タノール群では，腺房細胞の側面細胞膜における微絨毛 や嵌合の異常形成とそれに伴う細胞間隙の拉大が著明 で，エタノール投与初期から常に観察された（写真10）. これと同様の所見は腺房細胞と介在部導管細胞間, 介在
部導管細胞間, 介在部導管細胞と線条部導管細胞間, 線 条部導管細胞間においてもエタノール投与 10 か以以後の ラットの一部に軽度に観察され，さらに，基底層に向か っての各部細胞の俥度の微䋐毛形成もエタノ一ル投与 10 か月以後に一部に観察された。 


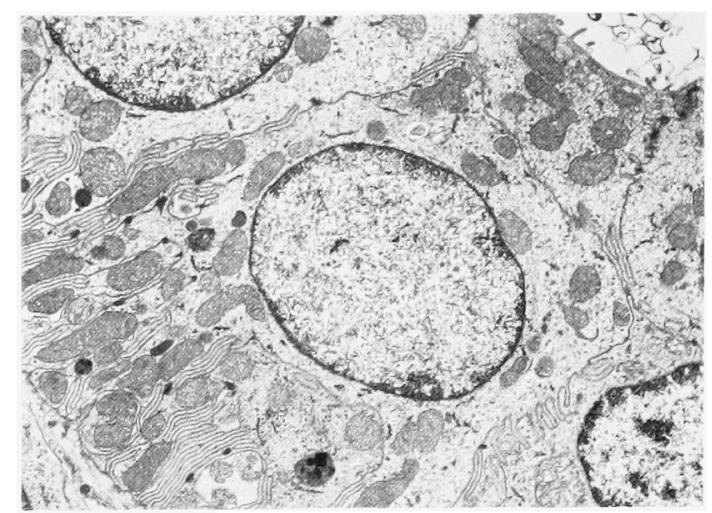

写真 6 対炤群の電顕像・線条部導管

(ラットNo. 11 飼育期間 8 か月) 線条部尊管細胞 の基底側に無数の陥入構造がみられ，その間にミト コンドリアが位置している。

$\times 5,000$

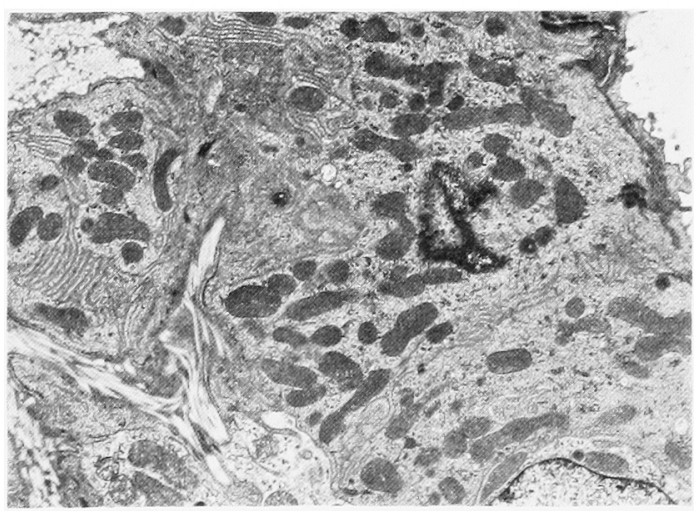

写真 7 エタノール群の電顥像・線条部導管

（ラットNo. 41 コタノール投与 10 か月）線案部導 管勫胞のミトコンドリアが暗い基質とクリスタの減 少を伴 5変性を示して管膑㑡に変位し, 線状棈造の 乱れが著明である。

$\times 5,000$

考

案

アルコール常習による耳下腺の無症侯性腫大は多数報 告されているがか7，てこで得られた生検，剖倹，造影 による所見によれば，耳下腺の腫大の原因は主に腺房細

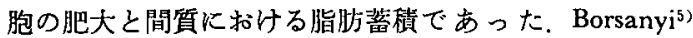
は腺房細胞の肥大は初期にみられ，脂肪場積や軽度の線 稚化が後期にみられる㑯向にあると述べている。

また, Seifert ${ }^{14)}$ は唾液腺症は，初期には分泌顆粒の增 加と腺房細胞の肥大によって唾液分泌が六進するが，次 いで分泌頖粒の減少と腺房細胞の水胞化による唾液分泌
表 9 毛細血管・末梢神経の電顕的所見

\begin{tabular}{|c|c|c|c|c|c|c|c|}
\hline \multicolumn{2}{|c|}{ 対 } & \multicolumn{2}{|l|}{ 群 } & \multicolumn{4}{|c|}{ ×タノール群 } \\
\hline $\begin{array}{c}\text { 餇 } \\
\text { 龍 } \\
\text { 划 } \\
\text { 間 } \\
\mathbf{a}\end{array}$ & 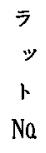 & $\begin{array}{l}\text { 毛 } \\
\text { 細 } \\
\text { 血 } \\
\text { 管 } \\
\mathrm{b}\end{array}$ & $\begin{array}{c}\text { 末 } \\
\text { 梢 } \\
\text { 神 } \\
\text { 経 } \\
\text { c }\end{array}$ & $\begin{array}{c}\text { 投 } \\
\text { 与 } \\
\text { 期 } \\
\text { 成 } \\
\text { d }\end{array}$ & $\begin{array}{c}\text { ラ } \\
ッ \\
\text { ト } \\
\mathrm{Na}\end{array}$ & $\begin{array}{l}\text { 毛 } \\
\text { 科 } \\
\text { 血 } \\
\text { 管 }\end{array}$ & $\begin{array}{l}\text { 林 } \\
\text { 梢 } \\
\text { 神 } \\
\text { 释 }\end{array}$ \\
\hline 5 & $\begin{array}{l}1 \\
2 \\
3\end{array}$ & $\begin{array}{l}- \\
- \\
-\end{array}$ & $\begin{array}{l}- \\
- \\
-\end{array}$ & 1 & $\begin{array}{l}27 \\
28 \\
29\end{array}$ & $\begin{array}{l}- \\
- \\
-\end{array}$ & $\begin{array}{l}- \\
\pm \\
-\end{array}$ \\
\hline 6 & $\begin{array}{l}4 \\
5 \\
6\end{array}$ & $\begin{array}{l}- \\
- \\
-\end{array}$ & $\begin{array}{l}- \\
- \\
-\end{array}$ & 2 & $\begin{array}{l}30 \\
31\end{array}$ & - & - \\
\hline & & & & 3 & $\begin{array}{l}33 \\
34 \\
35\end{array}$ & $\begin{array}{l}- \\
- \\
-\end{array}$ & $\begin{array}{l}+ \\
\pm \\
-\end{array}$ \\
\hline 8 & $\begin{array}{l}10 \\
11 \\
12\end{array}$ & $\begin{array}{l}- \\
- \\
-\end{array}$ & $\begin{array}{l}- \\
- \\
-\end{array}$ & 4 & $\begin{array}{l}36 \\
37 \\
38\end{array}$ & $\begin{array}{l}- \\
- \\
-\end{array}$ & $\begin{array}{l} \pm \\
- \\
\pm\end{array}$ \\
\hline 10 & $\begin{array}{l}14 \\
15\end{array}$ & $\begin{array}{l}- \\
-\end{array}$ & $\begin{array}{l}- \\
-\end{array}$ & 6 & $\begin{array}{l}39 \\
40 \\
41\end{array}$ & $\begin{array}{l}- \\
- \\
-\end{array}$ & $\begin{array}{l}- \\
- \\
-\end{array}$ \\
\hline & & & & 8 & $\begin{array}{l}42 \\
43 \\
44\end{array}$ & $\begin{array}{l}- \\
-\end{array}$ & $\begin{array}{l}- \\
- \\
-\end{array}$ \\
\hline & & & & 10 & $\begin{array}{l}45 \\
46 \\
47\end{array}$ & $\begin{array}{l}- \\
- \\
-\end{array}$ & $\begin{array}{l}- \\
- \\
-\end{array}$ \\
\hline & & & & 12 & $\begin{array}{l}48 \\
49\end{array}$ & $\begin{array}{l}- \\
-\end{array}$ & $\begin{array}{l} \pm \\
-\end{array}$ \\
\hline & & & & 22 & $\begin{array}{l}51 \\
52\end{array}$ & $\begin{array}{l}+ \\
+\end{array}$ & $\begin{array}{l}+ \\
+\end{array}$ \\
\hline
\end{tabular}

\footnotetext{
a , d , e 表 3 索参胚

b micropinocytotic vesicle の減少

c 軸唋突起の変性
}

の低下が起こり，さらには腺実質の減少，脂肪蓄積，線 維化といった経過をたどり，契質の傷害の程度によって は再生を示すとしている。

栄養障害による耳下腺腫大の報告例も多いが8 10)，栄 養障害とフルコール常習とは密接な関連性があるという

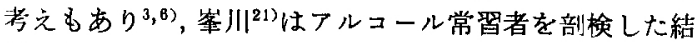
果，軽度のアルコールは食欲促進剤として働く，饮酒 量が多くなれば食触は減少し低栄養状態になると指摘し 


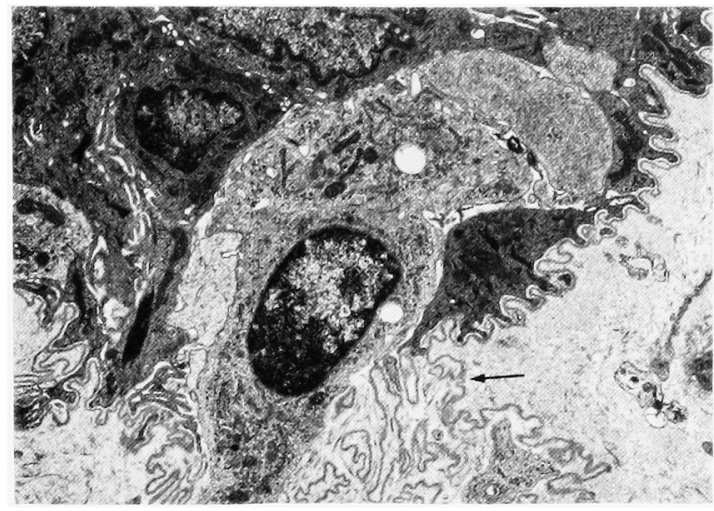

写真 8 エタノール群の電顕像・線条部導管

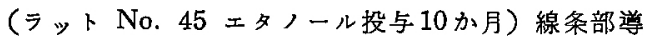
管細胞において，不規則に重層した基底膜が認めら れる (矢印).

$\times 5,000$

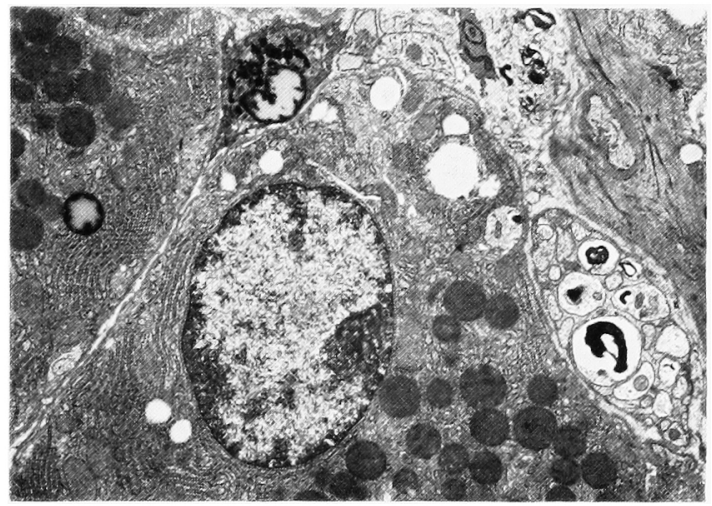

写真 9 エタノール群の電影像

（ラットNo. 38 ェタノール投与 4 か月）膨化した 神経軸索突起内にミニリン像の增加と神経細線䧽の 減少が認められる。

$\times 5,000$

ている.

緒言で述べたように，アルコール常習者に括ける耳下 腺機能六進の報告があり ${ }^{1,5,7) ， ま た ， A l a p p a t t ~ ら ~}{ }^{22)}$ は 糖尿病患者の尰大した耳下腺に和ける機能元進の報告を

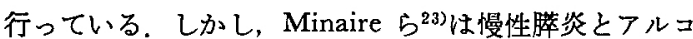
一ル性肝硬変患者に和ける唾液分泌量と重炭酸塩および アミラーゼの分泌減少を認め, Grimmel ら²4)，McColl ら ${ }^{25)}$ も同様の所見を得ている。 また，Maier ら ${ }^{19)} は ェ タ$ ノールを投与したラットで，耳下腺からの唾液量，アミ ラーゼ活性, ナトリウム濃度の減少を認めている。

本実験で得た所見では，腺房部の主な変化は，エタ， ール投与 3 か月からの低電子密度で均質な粘液性顆粒の 增加，エタノール投与 6 加月以後の分泌顆粒の娍少扣よ

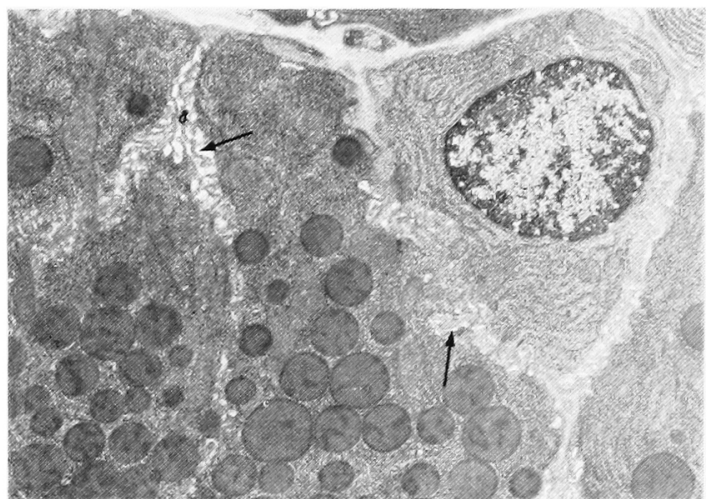

写真 10 ×ノール群の電影像・腺房細胞 （ラットNo. 33 エタノール投与 3 か月）腺房細胞

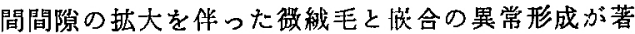
明である(知)。

$\times 5,000$

び腺房部の萎縮などであった，しかし，脂肪蓄積や腺房 細胞に招ける脂肪浸潤は比較的軽度で, Hemenway ら ${ }^{3)}$ による“a few small clumps of normal appearing acini”を形成するような脂肪蓄積はあまりみられなかっ た，また，腺房細胞の肥大るほとんどみられなかった。

Takeuchi $5^{26)}$ は不均質な顆粒の高電子密度部にアミ ラーゼを中心とする消化酵素の存在を認めて批り，した がって著者の得た均質な低電子密度の顆粒の增加や分泌 顆粒の減少といら所見は, Duggan ${ }^{10)}$, Borsanyi $^{5)}$, のア ルコール常習者に拈けるアミラーゼ上昇といら報告とは 一致しない.

導管の変化に関する記述は少ないが，そのなかで池田 ら 27)はアルコール常習者の耳下腺造影を行い，導管の狭 窄, 拡張，壁の不整像，走行の乱れを高率に認めてい る、本実験に㧤いて子，エタノール投与 4 か月から，介 任部導管が狭窄あるいは拡張しながら增生しているのが 認められた。エタノール投与10か月のラット 3 匹にみら れたこの介在部導管の増生と腺房細胞の减少，腺房部の 萎縮, 線維組織の増加などの所見を示す小葉単位の病変 は，本実験に用いたラットの膵の検索で得られた所見 ${ }^{28)}$ とまったく類似したものであり，同時に，ヒト慢性膵炎 の特徵像とされている Edmondson ら ${ }^{293}$ とる “ductular hyperplasia", Sarles ${ }^{30)}$ にる “canalicular dedifferentiation”の所見と一致したものであった.

ところで, 介在部導管細胞の管腔側に認められた PAS 陽性の電顕的には高電子密度で均質な小型の顆粒は，お

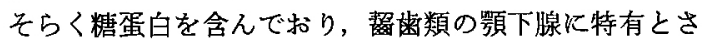
れる Pinkstaff ${ }^{31)}$ によるわゆる顆粒性導管に含まれて いる顆粒と同様に，なんらかの内分泌機能を有している ものと考劣られる。近年, Smith ら ${ }^{32}$ はラット耳下腺の 介在部にインシュリン様物質を認めたと報告している. 
また，線条部導管細胞の管腔側においてて観察された電 子密度の低い小型の顆粒状構造物は, 介在部導管細胞の PAS 陽性顆粒とは異なり，いまだ記载がなくその意義 も不明である。

線条部の変化は光顕的には乏しかったが，電影的には エタノール投与初期からミトコンドリアの変性, 管腔側 への変位，基底側細胞質の白質化（基底陷入の消失）に よる線状楧造の変化が涩められた。

Sharawy ら ${ }^{33)}$ はマウス買下腺の腺房紐胞におけるミ トコンドリアと細胞膜の接近は ATP 産生部（ミトコン ドリア）とATP 利用部（細胞膜）との接近を意味し， 血液の形成や分泌に必要なエネルギー供給を容易にする と述べている。耳下腺線条部梴管上皮細胞の基底側線条 構造に類似した構造は, 腎の遠位尿細管においてもみら れ，そこでは水や電解質の再吸收が行われていることが よく知られている。また，Katsuyama らは ${ }^{34)}$ 膵におい ては腺房中心細胞を主とする導管上皮が電解質の輸送に 闺与するとしており，耳下脉では同様の機能を線条部導 管が果たすと考えられている35). したがって, 線条部導 管における基底側細胞膜の傷害やミトコンドリアの異常 は, 重炭酸塩を中心とする電解質の分泌濃度にも变化を きたするのと考えられる。

耳下腺における内分泌機能の存在が報告され ${ }^{32,36)}$, 組 織学的にも機能的にも耳下腺之脺との類似性は指摘され てきた。 また，糖尿病患者の $41 \%$ に耳腺の隀大があり 耳下腺の触診は粭尿病の存在を知るのに重要な意義を有 するとする報告 ${ }^{12)}$ や，慢性脺炎患者における耳下腺の䟚 液分泌低下 ${ }^{25,37)}$ 中実験的急性膵炎において耳下腺の腺房

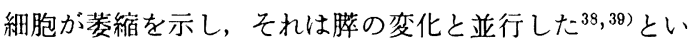
ら報告, さらには Sjögren 症候群患者の耳下腺管上皮細 胞と萑管上皮紐胞に共通の抗体を認めたという報告 ${ }^{40)}$ どにより耳下腺と膵との間には密接な反応性の存在する ことが推察された，実際，Kakizaki ら ${ }^{11)}$ は共生ラット を使って膵と耳下腺間の体液性機構による闺連性を立詿: したとしている。

このような耳下腺と粹との反応性を背景に McColl ら ${ }^{25)}$ は, アルュール摂取時の耳下腺の変化はアルコール のみによるのではなく，膵との関連性も加わっているで あろらと述べている。

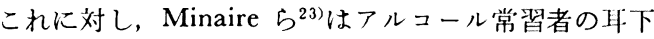
腺の機能低下はパラフィルムを咬むことによる刺激で減 少し，したがって耳下腺の機能低下は感受性低下による ものであると判断した。 また，Perec ら ${ }^{42)}$ は 3 か月間エ タノールを投与したラットの耳下腺で交换神経性および 副交感视経性刺激に対する感受性の低下がみられたこと を報告しており，Barat1i ら ${ }^{13)}$ も同様の結果を得たとし ている.

本些験におけるもっとも初期の耳下腺の变化は，腺房 紏胞間細胞膜の紏胞間隙の挑大を伴った漠合の異常形成
であった。これは本実験に使用したラットの膵の検索で 得られた所見 ${ }^{29)}$ と同一で，発生時期むほとんど同時であ った。また，神経組織の変化も27匹中 8 匹（30\%）にみ られたが，散発的で耳下腺に対して高度の影響を与えて いるようには考えられなかった。

ところで，エタノールの血中濃度と耳下腺管内液の濃 度はほとんど同程度で、エタノールは代謝されずにその まま耳下腺管に分泌されることが知られている ${ }^{44,15)}$ 。そ れはエタノールが細胞質や細胞間隙を通って導管へ分泌 されることを意味すると考えられる。また，エタノール の肝に対する直接的傷害を認める報告 ${ }^{15,16) や エ タ ノ ー ル ~}$ の毒性は肝だけではなくエタノール代謝に関与しない器 官においても作用するという報告もある ${ }^{46)}$.

また，Nakamura ら ${ }^{47,48)}$ は，高い細胞密度での培養 では肝細胞の分化が高度に進むが，しかし，細胞の増殖 は抑制され，再生途上の肝細胞では細胞間の接触が粗に なって增殖に移行し，それらの相反柧整は細胞膜面に存 在する調節器によって行われているようにみえると報告 している.

さらに, Traub ら ${ }^{49)}$ は肝部分切除後の訮紐胞におい $て$ gap junction が消失し, 練胞間の電気的結合も失わ れたことを報告している。

本実験における細胞膜の変化はアルコール特有のもの ではなく，傷害に対する基本的な反応と考学るべきであ ろう。しかし，細胞間隙の拡大が耳下腺においても再生 あるいは增殖を引き起こす可能性は高い，これに加え， 細胞膜における緩慢な長期にわたって持続する退行性変 化は，細胞膜が腺房細胞に対して特異的に有する正常な 機能を抑制する可能性がある。このようなエタノールで 誘発された分化，成熟の抑制および緩慢に進行する再生 が，ヒト慢性膵炎の特徵とされる “ductular hyperplasia”29) の像に非常に類似した組織像を耳下腺にもたらし たものと考えられる。

したがって，哧液分泌の減少は，膵との関連 ${ }^{25,11) や 耳 ~}$ 下腺の感受性の低下 ${ }^{23,42,43)}$ というより, エタノ一ルの直 接的あるいは間接的影響による耳下腺組織自体の変化に よって起こると考えられた。

以上のような結果から，エタノール長期提取による耳 下腺の組織変化は次のような機序によって起こると考え られた。

まず，提取されたェタノールは基底細胞膜を通して細 胞内に取り込まれるが，腺房細胞間細胞膜では莰合の異 常形成，細胞間隙の開大が起こり，そこを直接ェタノー ルが通過するようになる。また，線条部導管細胞では基 底側紐胞膜に変化が生じる。これらの細胞膜の障害によ り細胞の再生過程で買常な抑制作用が起こる. 次いで, 㟫房細胞および線条部導管細胞の補充細胞としての役割 を担らと考えられる介在部導管紐胞が, 前 2 者の変化に 応じて不規則な增生を起こし，不規則な延長による介在 
部導管の拡張あるいは狭窄を生じる。これらの結果, 末 梢の腺房細胞は退行变性をきたして萎縮し，しだいに線 維組織に置換されるようになる。

\section{結語}

エタノール長期投与時における耳下腺の組織变化を解 明する目的で, Wistar 系ラットに $20 \%$ エタノールを経 口投与し, 耳下腺の光顕的, 電顕的検索を行った結果, 次のような成績を得た。

1. 光顕的には，エタノール群の 3 匹 (11\%) のラッ トに执いて, 小葉単位で高度の病的変化が観察され，さ らに類似した軽度の変化が 8 匹（30\%) において小葉内 で散見された。これらのラットでは線維化を伴う導管増 生の像が認められた。

2. 電顕的には，腺房細胞ならびに小導管上皮細胞に 種々の变化が観察された。初期から共通してみられた変 化は, 腺房細胞間細胞膜と線条部導管細胞における变化 であった。それは細胞間隙の拡大を伴った腺房細胞間の 微絨毛と嵌合の異常形成と, ミトコンドリアの高度変性 を伴った線条部導管細胞における基底側線条構造の消失 であった。 また，エタノール投与 4 か月以後には介在部 導管の増生と不規則な延長が強く認められた。

以上の成績から，エタノールの直接的作用により，最 初に腺房細胞間の細胞膜と線条部導管細胞の基底側細胞 膜が傷害され，それらの修復過程で介在部導管の再生， 增殖, 不規則な延長が起こり, 腺房細胞に退行变性, 萎 縮をきたし, 耳下腺の唾液分泌機能が低下寸ると推測さ れた。

稿を終えるにあたり，こ指尊，こ校閲を赐りました東 北大学蒌学部第 2 口腔外科学教室, 手島貞一教授に深甚 なる謝意を捧げます。また本研究に多大なこ教示，こ助 言を頂きました仙台社会保険病院の中村克宏先生に感謝 いたしますとともに，こ協力頂きました公立志津川総合 病院院長柿崎五郎先生はじめ同病院職員各位に厚く扰礼 申し上げます。

本論文の要旨は, 第33回日本口腔外科学会総会（昭和 63年 9 月几，名古屋）に扰いて発表した。

\section{引用 文 献}

1) Borsanyi, S. J. and Blanchard, C.: Asymptomatic enlargement of the parotid gland in alcoholic cirrhosis. South Med J 54:678-682 1961.

2) Abelson, D.C., Mandel, J.D., et al.: Salivary studies in alcoholic cirrhosis. Oral Surg 41: 188-192 1976.
3) Hemenway, W.G. and Allen, G.W.: Chronic enlargement of the parotid gland: Hypertrophy and fatty infiltration. Laryngoscope 69: 1508-1522 1959.

4) Kaltreider, H.B. and Talal, N.: Bilateral parotid gland enlargement and hyperlipoproteinemia. JAMA 210: 2067-2070 1969.

5) Borsanyi, S. J.: Chronic asymptomatic enlargement of the parotid glands. Ann Otol Rhinol Laryngol 71: 857-867 1962.

6) Wolfe, S. J., Summerskill, W.H.J., et al.: Parotid swelling, alcoholism and cirrhosis. N Engl J Med 256: 491-495 1957.

7) Mandel, L. and Baurmash, H.: Parotid enlargement due to alcoholism. JADA 82: 369-373 1971.

8) Du Plessis, D. J.: Parotid enlargement in malnutrition. S Afr Med J 28: 700-703 1956.

9) Katsilambros, L.: Asymptomatic enlargement of the parotid glands. JAMA 178: 513-514 1961.

10) Duggan, J. J. and Rothbell, E.N.: Asymptomatic enlargement of the parotid glands. $\mathrm{N}$ Engl J Med 257: 1262-1267 1957.

11) Davidson, D., Leibel, B.S., et al.: Asymptomatic parotid gland enlargement in diabetes mellitus. Ann Intern Med 70: 31-38 1969.

12）平田幸正，西村ひろみ，他：糖尿病に打ける耳 下腺腫大と Dupuytren 拘樎. Diabetes Journal 1: 75-77 1973.

13) Russotto, S.B.: Asymptomatic parotid gland enlargement in diabetes mellitus. Oral Surg 52: 594-598 1981.

14) Seifert, G.: Zur Pathogenese der Speicheldrüsenschwellung (Sialadenose). Verh Dtsch Ges Pathol 46: 250-256 1962.

15) Lieber, C.S., Jones, D.P., et al.: Effects of prolonged ethanol intake: production of fatty liver despite adequate diets. J Clin Invest 44: 1009-1021 1965.

16) Rubin, E. and Lieber, C.S. . Fatty liver, alcoholic hepatitis and cirrhosis produced by alcohol in primates. N Engl J Med 290:1281351974.

17) Dreiling, D.A., Richman, A., et al.: The role of alcohol in the etiology of acute pancreatitis. The effect of intravenous alcohol on the external secretion of the pancreas. Gastroenterology 20: 636-646 1952.

18) Sarles, H., Lebreuil, G., $\epsilon t$ al.: A comparison of alcoholic pancreatitis in rat and man. Gut 12: 377-388 1971.

19) Maier, H., Born, I.A., et al.: The effect of chronic ethanol consumption on salivary gland morphology and function in the rat. 
Alcoholism: Clinical and Experimental Research 10: 425-429 1986.

20) Luft, J.H.: Improvements in epoxy resin embedding methods. J Biophys Biochem Cytol 9: 409-414 1961.

21）峯川宏一：フルコール性畈障害時に打ける顎下 腺の変化。日大医誌 43：459-473 1984.

22) Alappatt, J.L. and Ananthachari, M.D.: A preliminary study of the structure and function of enlarged parotid glands in chronic relapsing pancreatitis by sialography and biopsy methods. Gut 8: 42-45 1967.

23) Minaire, Y., Descos, L., et al.. Chronic pancreatitis, alcoholic liver cirrhosis and salivary secretion. Digestion 12: 57-60 1975.

24) Grimmel, K., Rossbach, G., et al.: Amylase activity of parotid saliva in acute and chronic pancreatitis. Acta Hepato-Gastroenterol 23: 334-344 1976.

25) McColl, K.E.L., Brodie, M.J., et al.: Parotid salivary gland function in patients with exocrine pancreatic insufficiency. Acta HepatoGastroenterol 26: 407-412 1979.

26) Takeuchi, T., Kameya, T., et al.. Development of exocrine cells of the pancreas and parotid gland in rats. Digestion 18: 266-279 1978.

27）池田浩之, 今野陽三，他：フルコール依存症に 扣ける耳下腺病変。内科 56：163-167 1985.

28) Kakizaki, G., Sasahara, M., et al.: On the pathogenesis of chronic alcoholic pancreatitis from the viewpoint of experimental results in rats. Int J Pancreatol 2: 101-116 1987.

29) Edmondson, H.A., Bullock, W.K., et al.: Chronic pancreatitis and lithiasis. A clinicopathologic study of 62 cases of chronic pancreatitis. Am J Pathol 25: 1227-1247 1949.

30) Sarles, H., Muratore, R., et al.. Aetiology and pathology of chronic pancreatitis. Bibl Gastroenterol 7: 75-120 1965.

31) Pinkstaff, C.A.: The cytology of salivary glands. Int Rev Cytol 63: 141-261 1980.

32) Smith, P.H. and Petel, D.G.. Immunochemical studies of the insulin-like material in the parotid gland of rats. Diabetes 33: 6616661984.

33) Sharawy, M., Schuster, G., et al.. Association of mitochondria with the plasma membrane of the acinar cells of the mouse submaxillary glands. Acta anat 102: 440-446 1978.

34) Katsuyama, T. and Spicer, S.S.: The surface characteristics of the plasma membrane of the exocrine pancreas. Am J Anat 148: 5355541977.
35) Schneyer, L., Young, I.A., et al.: Salivary secretion of electrolytes. Physiol Rev 52:7207771972.

36) Cantin, M., Gutkowska, J., et al.. Immunocytochemical localization of atrial natriuretic factor in the heart and salivary glands. Histochemistry 80: 113-127 1984.

37) Noronha, M., Dreiling, D.A., et al.: The parotid and pancreas. IV Parotid secretion after secretin stimulation as a screening test of pancreatic dysfunction. Am J Gastroenterol 70: 282-285 1978.

38) Kakizaki, G., Noto, N., et al.: Histologic findings of the parotid gland and bicarbonate content in parotid saliva of dogs with experimentally produced pancreatitis. Tohoku J Exp Med 108: 165-177 1972.

39) Ishidate, T., Senoo, A., et al.: An electron microscopic study of the pancreas and parotid gland of rats with experimental acute pancreatitis. Tohoku J Exp Med 113: 213-223 1974.

40) Ludwig, H., Schernthaner, G., et al.: Antibodies to pancreatic duct cells in Sjögren's syndrome and rheumatoid arthritis. Gut 18: 311-315 1977.

41) Kakizaki, G., Sasahara, M., et al.: Mechanism of the pancreas-parotid gland interaction. Am J Gastroenterol 70: 635-644 1978.

42) Perec, C.J., Celener, D., et al.. Effects of chronic ethanol administration on the autonomic innervation of salivary glands, pancreas and heart. Am J Gastroenterol 72: 46-59 1979.

43) Baratti, C.M., Rubio, M.C., et al.: Effect of chronic alcohol feeding on adrenergic and cholinergic neurotransmission mechanism. Am J Gastroenterol 73: 21-27 1980.

44) Friedemann, T.E., Motel, W.G., et al.: The excretion of ingested ethyl alcohol in saliva J Lab Clin Med 23: 1007-1013 1938.

45) McColl, K.E.L., Whiting, B., et al.: Correlation of ethanol concentrations in blood and saliva. Clin Sci 56: 283-286 1979.

46) Rubin, E. and Rottenberg, H.: Ethanolinduced injury and adaptation in biological membranes. Federation Proceedings 41: 246524711982.

47) Nakamura, T., Yoshimoto, K., et al.: Reciprocal modulation of growth and differentiated functions of mature rat hepatocytes in primary culture by cell-cell contact and cell membranes. Proc Natl Acad Sci USA 80: 7229-7233 1983.

48) Nakamura, T., Nakayama, Y., et al.: Reci- 
Vol. 35 No. 4

procal modulation of growth and liver functions of mature rat hepatocytes in primary culture by an extract of hepatic plasma membranes. J Biol Chem 259: 8056-8058 1984.

49) Traub, O., Drüge, P.M., et al.: Degradation and resynthesis of gap junction protein in plasma membranes of regenerating liver after partial hepatectomy or cholestasis. Proc Natl Acad Sci USA 80: 755-759 1983. 